\title{
Effects of specific nutrients on tax-dependent activation of NF- $\kappa$ B and MMP-9 in human T-cell lymphotropic virus -1 positive malignant T-lymphocytes
}

\author{
Steve Harakeh ${ }^{1 *}$, Mona Diab-Assaf ${ }^{2}$, Rania Azar ${ }^{2}$, Esam Azhar ${ }^{1,3}$, Ghazi A. Damanhouri ${ }^{1}$, Adeel Chaudary ${ }^{1,3}$, \\ Haitham Yacoub ${ }^{4}$, Mourad Assidi ${ }^{5}$, Muhammad M. Abu-Elmagd ${ }^{5}$, Mohammed H. Alqahtani $^{5}$, Adel M. Abuzenadah ${ }^{5}$ \\ , Taha Kumosani ${ }^{1}$, Aleksandra Niedzwiecki ${ }^{6}$, Mathias Rath $^{6}$, Elie Barbour ${ }^{7}$
}

From 2nd International Genomic Medical Conference (IGMC 2013)

Jeddah, Kingdom of Saudi Arabia. 24-27 November 2013

\section{Background}

Adult T-cell Leukemia (ATL) is a disease with no known cure so farand it is a resistant to chemotherapy. The virus can be transmitted by exchange of bodily fluids through the placenta and from mother to child. Only $5 \%$ of those who are infected develop the disease after a long latency period ranging from 30-50 years $[1,2]$. The disease manifests itself as an aggressive proliferation of $\mathrm{CD}^{+}$cells with the human T-cell Lymphotropic virus type 1 (HTLV-1) [3]. The leukemogenesis of the virus is mainly attributed to the viral oncoprotein, Tax, that activates the Nuclear Factor kappa B (NF- $\kappa \mathrm{B}$ ) which in turn stimulates the activity and expression of the matrix metalloproteinase-9 (MMP-9)which is important in angiogenesis[2]. Our previous work has shown that using non-cytotoxic concentrations of a Specific Nutrient Synergy (SNS)mixture resulted in the induction of apoptosis in both HTLV-1 positive and negative malignant T-lymphocytes [1]. The objective of this study is to investigate the efficacy of SNS on Tax expression, NF- $\kappa \mathrm{B}$ levels as well as on MMP-9 activity and expression both at the transcriptional and translational levels intwo HTLV-1 positive cell lines, HuT-102 and C91-PL.

\footnotetext{
* Correspondence: sharakeh@gmail.com

${ }^{1}$ Special Infectious Agents Unit, King Fahd Medical Research Center, King

Abdulaziz University, Jeddah, Kingdom of Saudi Arabia

Full list of author information is available at the end of the article
}

\section{Materials and methods}

Cell growth, experimental design, source of SNS, preparation and storage of stock solution, were previously described by our group [1].The effects of non-cytotoxic concentrations of SNS ranging from $0-350 \mu \mathrm{g} / \mathrm{ml}$ were evaluated for their efficacy on proliferation, Tax expression, NF- $\kappa$ Bmobility and the activity and expression of MMP-9 at 48h and 96hof incubation.Cytotoxicity of EGCG was assayed using CytoTox 96 Non-radioactive and proliferation was measured using Cell Titer $96^{\mathrm{TM}}$ Nonradioactive Cell Proliferation kit( MTT- based assay). Elisa and EMSA were used to assess the effect of SNS on NF- $\kappa$ Bmobility. Zymography was used to determine the effects of SNS on the activity and secretion of MMP-9. The expression of MMP-9 was done using RTPCR at the translational level and Immunoblottingat the transcriptional level.

\section{Results}

A significantinhibition of proliferation was seen in both cell lines starting at a concentration of $200 \mu \mathrm{g} / \mathrm{ml}$ and in a dose dependent manner. SNS induced a dose dependent decrease in Tax expression (Fig.1),which was paralleled by a down-regulation of the nuclearization of NF- $\kappa \mathrm{B}$ (Fig.2). This culminated in the inhibition of the activity of MMP-9 and their expression both at the transcriptional and translational levels (Fig.3). 

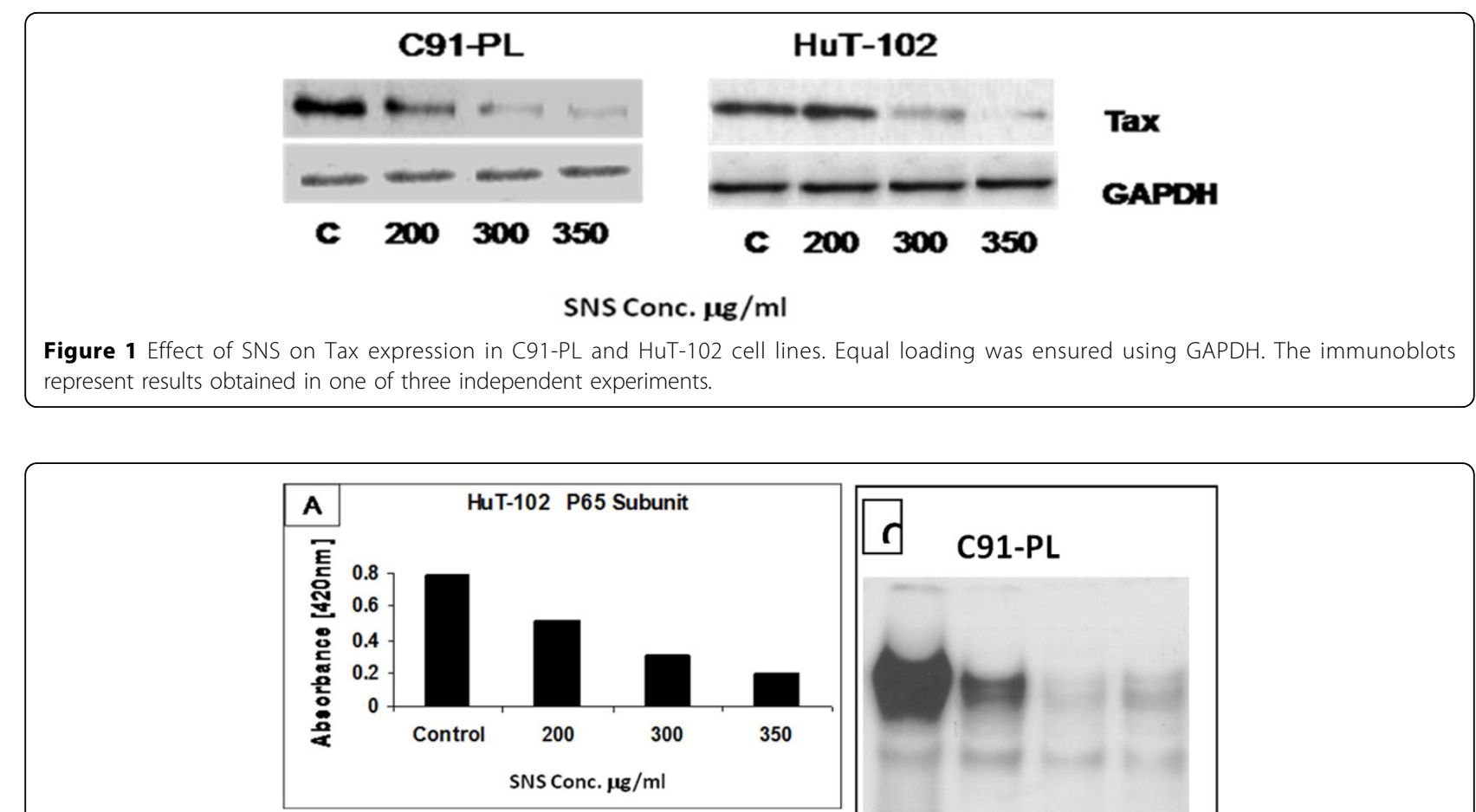

Figure 2 Effect of SNS on NF- $\kappa$ B nuclear translocation in HuT-102 and C91-PL HTLV-1 positive cell lines. (A,B) Nuclear levels of P65 subunit of $\mathrm{NF}-\kappa \mathrm{B}$ was evaluated by ELISA at 48 and $96 \mathrm{~h}$ of incubation. Each value is the mean \pm SD deduced from three separate experiments done in triplicate. (C) EMSA Gel representing one of three independent experiments with nuclear extracts of C91-PL.

A
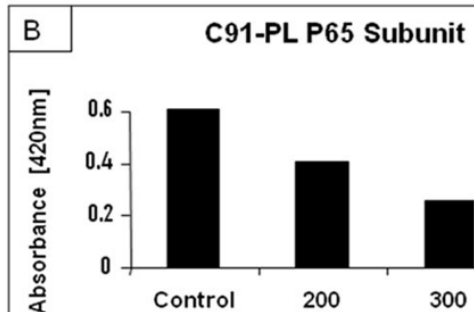

0

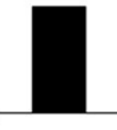

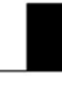

350

SNS Conc. $(\mu \mathrm{g} / \mathrm{ml}$

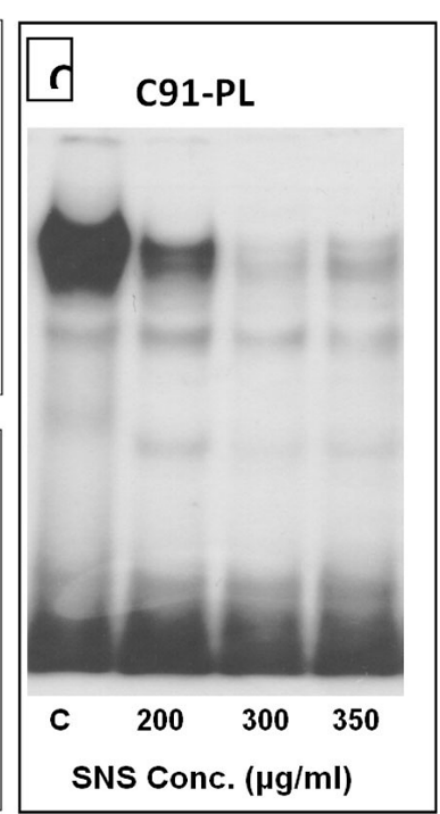

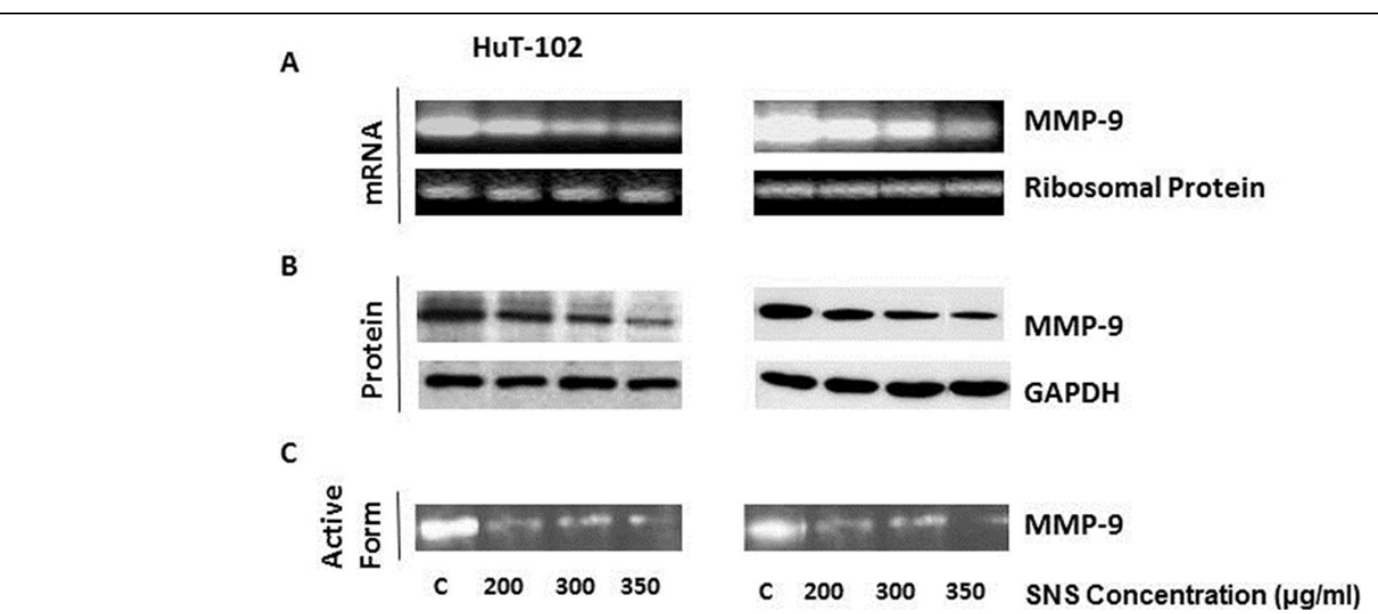

Figure 3 Effect of SNS on MMP-9 mRNA (a), protein (b) and activity (c) in two ATL-HTLV-1 positive cell lines. Equal loading was ensured using ribosomal protein for mRNA expression (a) and GAPDH for protein expression (b).The results represent one out of three independent experiments. 


\section{Conclusions}

The role of nutrients in the treatment of disease has been overlooked for a long time. Recently, it has been recognized that nutrients play a crucial role in the outcome of the treatment. The results of this study indicate that a specific nutrient synergy targeted multiple levels pertinent to the progression of ATL. Its activity was mediated through the NF- $\kappa$ B pathway, and hence has the potential to be integrated in the treatment of this disease as a natural, yet potent anticancer agent.

\section{Authors' details}

'Special Infectious Agents Unit, King Fahd Medical Research Center, King Abdulaziz University, Jeddah, Kingdom of Saudi Arabia. ${ }^{2}$ Molecular

Tumorigenesis and Anticancer Pharmacology, Lebanese University, Hadath, Lebanon. ${ }^{3}$ Department of Medical Laboratory technology, Faculty of Applied Medical Sciences, King Abdulaziz University, Jeddah, Kingdom of Saudi Arabia. ${ }^{4}$ Biological Sciences Department, Faculty of Sciences, King Abdulaziz University, Jeddah, Kingdom of Saudi Arabia. ${ }^{5}$ Center of Excellence in Genomic Medicine Research, King Abdulaziz University, Jeddah, Kingdom of Saudi Arabia. ${ }^{6}$ Dr. Rath Research Institute, Santa Clara, CA, USA. ${ }^{7}$ Department of Animal and Veterinary Sciences, American University of Beirut, Lebanon.

Published: 2 April 2014

\section{References}

1. Harakeh S, Diab-Assaf M, Niedzwiecki A, Khalife J, Abu-El-Ardat K, Rath M: Apoptosis Induction by Epican Forte in HTLV-1 Positive and Negative Malignant T-cells. Leukemia Research 2006, 30(7):869-881.

2. Harakeh S, Diab-Assaf M, Azar R, Tayeb S, Abou-El-Ardat K, Damanhouri GA, Qadri I, Chaudhary A, Kumosani T, Hassan H, Niedzwiecki A, Rath M,

Yacoub H, Barbour E: Epigallocatechin-3-gallate inhibits Tax-dependent activation of Nuclear Factor Kappa B and of Matrix Metalloproteinase 9 in Human T-cell Lymphoropic Virus -1 positive leukemia cells. Asian Pac $J$ Cancer Prev 2014.

3. Boxus $M$, Willems $L$ : Mechanisms of HTLV-1 persistence and transformation. Br J Cancer 2009, 101:1497-1501.

\section{Submit your next manuscript to BioMed Central} and take full advantage of:

- Convenient online submission

- Thorough peer review

- No space constraints or color figure charges

- Immediate publication on acceptance

- Inclusion in PubMed, CAS, Scopus and Google Scholar

- Research which is freely available for redistribution

Submit your manuscript at www.biomedcentral.com/submit 